\title{
Hjemløsheden, rejsen og den kronotopiske identitet - en litteraturteoretisk analyse af en selvbiografisk kræftfortælling
}

\section{Nina Henriksen}

Institut for Sundhedstjenesteforskning, Syddansk Universitet nihenriksen@health.sdu.dk

Henriksen, N. (2014). Hjemløsheden, rejsen og den kronotopiske identitet - en litteraturteoretisk analyse af en selvbiografisk kræftfortælling. Tidsskrift for Forskning $i$ Sygdom og Samfund, nr. 20, 113-143.

Artiklen indeholder en analyse af en selvbiografisk kræftfortælling. Gennem inddragelsen af litteraturteori, der beskæftiger sig med litteraturens fremstilling af tid og rum og med rejsens metafor, undersøger artiklen de tider og steder, som den udvalgte selvbiografi kortlagger og tematiserer. Formålet med artiklen er at vise, hvordan det ser ud, og hvad det betyder, når kræftsygdommen $i$ dette tilfalde medvirker til at skabe en fortælling, som problematiserer en lineær opfattelse af tid, fortælling og identitet, og som specifikt gør op med idealet for den konventionelle kronologisk-lineære fortælling om 'kræften som en rejse'. Selvbiografien skaber således en iøjnefaldende litterær topografi, som trækker på en særlig inddragelse af rejsen som en metafor for livet med en kræftsygdom. Forfatteren er en usædvanlig rejsende, som befinder sig $i$ en tilstand af at være permanent 'ude af kurs' $i$ tid og sted, og fortællingen kortlægger en eksistentiel hjemløshed. Den eksistentielle hjemløshed spejler sig i en særlig anskuelse af identiteten, som artiklen begrebsliggør som en 'kronotopisk identitet'. Den 'kronotopiske identitet' forsøger ikke at besvare spørgsmålet 'hvem er jeg?' eller at forstå selvet i en kronologisk orden, men at skabe et rum for refleksion over 
spørgsmålet 'hvor er jeg?' og 'hvor er jeg på vej hen?'. Artiklen ønsker at demonstrere, hvordan selvbiografien tydeligt adskiller sig fra de uløseligt forbundne begreber om narrativ identitet og narrativ kohærens og at udfordre den fælles kulturelle forståelse af relationer mellem kræft, tid og identitet, der er knyttet til anvendelsen af den konventionelle metafor om 'kræftrejsen'.

\section{Homelessness, the journey and the chronotopic identity - a literary theoretical analysis of an autobiographical cancer narrative}

The article draws on literary theories and unfolds as an analysis of a Danish breast cancer narra-tive. It analyzes the use of the metaphor of the journey and the topographies and temporalities being involved in the narrative representation of breast cancer. The purpose of the article is to show how it looks and what it means when cancer contributes to create a narrative which debates linear conceptions of time, narrative, and identity and which revolts against the ideal of the con-ventional chronological linear narrative of 'cancer as a journey'. The dislocation of the self is related to an existential homelessness, to the use of the metaphor of the journey and to the con-struction of what could be termed a chronotopic identity, distinguished by a general restlessness, not trying to uphold and define space, time, and self in a chronological order, but rather trying to create a room for reflection, not on the matter of 'Who am I?' but rather 'Where am I?' and 'Where am I going'. The article wants to demonstrate how the narrative strongly differs from the widespread intertwined concepts of 'narrative identity' and 'narrative coherence' and hence translates into an alternative versioning of identity and narrative and to challenge the use of the cultural conventional metaphor of the 'cancer journey'.

\section{Introduktion}

Jeg vil ikke være her. Jeg vil ikke have det her liv. Den her fremtid. Der er ikke nogen fremtid. Engang var jeg god til at finde på. Hvis jeg ikke kunne komme den mest direkte vej frem, så fandt jeg på omveje, indirekte veje, snirklede og snoede veje og stier - og glemte tit, hvor jeg var på vej hen i den store sammenhæng, for dér hvor jeg var, var der noget, der optog mig. Jeg synes jeg har glemt, hvordan jeg finder på andre veje at gå. Så nu går tiden bare med mig.

Vingefang p. 121 


\section{Selvbiografiske kræftfortællinger som genre}

Selvbiografiske sygdomsfortællinger, såkaldte patografier (Hawkins, 1993) og autopatografier (Couser, 1997), udgives i stadigt stigende grad i bogform. Internationalt set eksisterer der et overvældende korpus af selvbiografisk sygdomslitteratur, der beskæftiger sig med stort set alle typer af sygdomme (Avrahami, 2007; Brody, 2003; Couser, 1997; Couser, 2009; DeShazer, 2005; Frank, 1995; Radley, 2009). I Danmark er den selvbiografiske sygdomslitteratur ligeledes i vækst, og ikke mindst selvbiografiske kræftfortællinger er vokset $i$ antal gennem de seneste år (Henriksen, 2011).

Indenfor den danske selvbiografiske kræftlitteratur kan man iagttage genremæssige variationer, som eksempelvis vedrører de typer af kræft, som de omhandler, og det er således muligt at kategorisere og inddele kræftlitteraturen i sygdomsspecifikke undergenrer (omend brystkræftlitteraturen kvantitativt overgår de andre) (Henriksen, 2011). Ligeledes kan den danske selvbiografiske kræftlitteratur inddeles i narrative undergenrer, såsom 'restitutionsfortælling' og 'selvhjælpsfortælling', der vedrører nogle af de genrer, som selvbiografierne hyppigt trækker på (Henriksen, 2011).

Selvom det ofte er selvbiografierne, som er skrevet af i forvejen offentligt kendte personer og forfattere, der eksponeres mest (Bro, 2004; Flyvholm, 2008; Gyldenkilde, 1999; Holm, 2009), er det et væsentligt særkende for de danske selvbiografiske kræftfortællinger, at omtrent 2/3 af dem er skrevet af førstegangsforfattere, der med kræften som anledning debuterer som forfattere (Henriksen, 2011). Således udgives kræftselvbiografierne både ved store etablerede forlag, ved mindre forlag og også på forfatternes 'egne forlag', og har derfor ikke i alle tilfælde været igennem en specifik professionaliseret og kommercialiseret redigeringsproces.

De danske selvbiografiske kræftfortællinger tilhører overordnet set populærgenren og adskiller sig dermed til en vis grad fra skønlitterært og specifikt kunstnerisk orienterede kræftfortællinger, herunder autoetnografiske bidrag til den selvbiografiske kræftlitteratur (Breast Cancer Fund, 1998; Conway, 2007; Frank, 1991; Spence, 1998; Stacey, 1997), som umiddelbart arbejder mere æstetisk bevidst og eksperimenterende og har flere retoriske, litterære og visuelle virkemidler til deres rådighed.

Det er uomtvisteligt, at den populære kræftselvbiografi selv inviterer til at blive læst som biografisk dokumentar og som autentisk førstepersons vidnesbyrd om sygdommen, og at den i høj grad bliver anskuet og læst på den måde, også i forskningen. Samtidig er det ikke uden relevans og betydning at kigge om bag selv- 
biografiernes mere eller mindre eksplicitte dokumentariske overflade eller netop at undersøge selvsamme overflade nøjere, ved at indkredse de æstetisk-litterære stiltræk, som selvbiografierne anvender for derved at blive i stand til at fortolke deres fulde virkefelt, herunder deres vedholdende brug og forarbejdning af almene kulturelt overleverede genrer og metaforer. Sagt med andre ord indeholder kræftdokumentaren altid mere end slet og ret dokumentar om den individuelle forfatters biografiske liv med kræft (Henriksen, 2011). Den danske selvbiografiske kræftlitteratur udgør således en særdeles righoldig, personligt forankret og forskelligartet litteratur, der sideløbende inddrager og fremskriver væsentlige fælles kulturelle æstetisk-litterære træk, som den medvirker til både at reproducere og udvikle.

Min artikel beskæftiger sig med én af de kulturelt set mest gennemtrængende og iøjnefaldende metaforer, som eksisterer i et utal af variationer og meget hyppigt inddrages i fortællinger om kræft, såvel som i andre sygdomsfortællinger. På baggrund af en litteraturteoretisk analyse af en udvalgt selvbiografisk kræftfortælling ønsker jeg således at vise, hvordan metaforen om 'kræften som en rejse' står i centrum af de eksistentielle overvejelser, sorger og længsler, som sygdommen bibringer forfatterens liv, herunder hvordan metaforen indgår i selvbiografiens opgør med en lineær opfattelse af tid, sted, fortælling og identitet. Således skaber fortællingen en iøjnefaldende kompleks identitetsspecifik litterær topografi, som hviler på en særlig inddragelse af rejsen som genre og som metafor for livet med kræftsygdommen.

\section{'Kræften som en rejse' - som metafor, genre og diskurs}

Metaforer om 'kræften som en rejse' og fortællinger om 'kræftrejser' optræder som en kulturelt set gennemgribende diskurs, der har stor indflydelse på den måde, hvorpå kræft fortælles, såvel i medierne (Seale, 2002) som i forskning (Harrington, 2012; Kendall \& Murray, 2005; Koch, 2008), herunder i forskning i klinisk kræftpraksis (Crane-Okada, 2007; Farquhar, Barclay, Earl, Grande, Emery \& Crawford, 2005; Fawcett, 2011; Hjelm, Hartwig \& Berterö, 2007; Nanton, Docherty, Meystre \& Dale, 2009; Reisfield \& Wilson, 2004; Skott, 2002; Yates, 2004), og i kræftpatienters beretninger og selvbiografiske fortællinger (Frank, 1995; Leydon, Bynoe-Sutherland \& Coleman, 2003; Semino, Heywood \& Short, 2004; Skott, 2002) ${ }^{1}$. Kræftrejsen fungerer simultant som et kognitivt skema for sygdomsforløbet med kræft og som fundamentet for et effektivt plot, en genre og en diskurs, der ofte 
bringes i anvendelse, når livet med kræft fortælles. Selvom kræftrejser beskrives forskelligt, og dele af litteraturen påpeger, at rejsen i nogle tilfælde kan føre til midlertidig desorientering (Fawcett, 2011; Reisfield \& Wilson, 2004), er det typiske billede, at rejsen beskrives som en lineær og målstyret rejse. Begreber som linearitet, kronologi og teleologi er således kendetegnende for det konventionelle skema, som hyppigt lægges til grund for forestillinger og fortællinger om kræftrejser (og for sygdomsrejser i det hele taget).

Metaforer om 'kræften som en rejse' og fortællinger om 'kræftrejser' optræder som en kulturelt set gennemgribende diskurs, der har stor indflydelse på den måde, hvorpå kræft fortælles, såvel i medierne (Seale, 2002) som i forskning (Harrington, 2012; Kendall \& Murray, 2005; Koch, 2008), herunder i forskning i klinisk kræftpraksis (Crane-Okada, 2007; Farquhar, Barclay, Earl, Grande, Emery \& Crawford, 2005; Fawcett, 2011; Hjelm, Hartwig \& Berterö, 2007; Nanton, Docherty, Meystre \& Dale, 2009; Reisfield \& Wilson, 2004; Skott, 2002; Yates, 2004), og i kræftpatienters beretninger og selvbiografiske fortællinger (Frank, 1995; Leydon, Bynoe-Sutherland \& Coleman, 2003; Semino, Heywood \& Short, 2004; Skott, 2002) . Kræftrejsen fungerer simultant som et kognitivt skema for sygdomsforløbet med kræft og som fundamentet for et effektivt plot, en genre og en diskurs, der ofte bringes i anvendelse, når livet med kræft fortælles. Selvom kræftrejser beskrives forskelligt, og dele af litteraturen påpeger, at rejsen i nogle tilfælde kan føre til midlertidig desorientering (Fawcett, 2011; Reisfield \& Wilson, 2004), er det typiske billede, at rejsen beskrives som en lineær og målstyret rejse. Begreber som linearitet, kronologi og teleologi er således kendetegnende for det konventionelle skema, som hyppigt lægges til grund for forestillinger og fortællinger om kræftrejser (og for sygdomsrejser i det hele taget).

Den konventionelle kræftrejse objektiverer sygdomsforløbet i et lineært bevægelsesmønster, der inkorporerer en lineær opfattelse af tid, fortælling og identitet (Koch, 2008). Rejsen udgår fra et mere eller mindre eksplicit (kropsligt, eksistentielt, følelsesmæssigt, kognitivt, identitets- og helbredsmæssigt) lav- eller nulpunkt og bevæger sig frem mod et forudbestemt veldefineret endemål, der er karakteriset af opnåelse af kropslig og mental ligevægt, i form af restitution af helbred og/eller rekonstruktion af krop og identitet. Det, som i udgangspunktet er tabt med kræftsygdommens komme, genfindes, genvindes eller rekonstrueres $i$ en eller anden form. I sin konventionelle udformning inkorporerer kræftrejsen således en idealiseret destination, der i tilfælde af at kropslig restitution eller helbredelse ikke er mulig, kendetegnes af eksistentiel, identitetsmæssig og følelsesmæssig forløsning, afklaring eller indsigt (Frank, 1995). 
Fælles for anvendelser af kræftrejsen som metafor og genre er, at de gør brug af betegnelser, der på forskellige måder relaterer til den konventionelle modermetafor 'livet er en rejse' (Lakoff \& Turner, 1989). Således anskues kræften typisk som en forhindring på livets vej, der skal overvindes eller som en hjælper på rejsen, der så at sige rydder eller retter vejen op, og dermed fungerer som anledning til bevidst at ændre livets kurs (Gibbs, Jr. \& Franks, 2002)). Rejsen involverer altså udvikling og forandring og har ofte karakter som et specifikt fremskridt (Gibbs, Jr. \& Franks, 2002; Segal, 2007). I nogle tilfælde kan den rejsende blive forsinket, og således understøttes kræftrejsediskursen eksempelvis også ved en aktuelt iøjnefaldende inddragelse af begrebet om 'patient-delay' i kræftforskning (Koch, 2008).

Kræftrejsen involverer en terminologi, der henfører til begyndelse og mål og inddrager motiver som stier, veje, omveje, tunneler, passager, etc. (Gibbs, Jr. \& Franks, 2002; Seale, 2002). Kræftrejsefortællingens indbyggede tidsregning og bevægelsesmønster er altså fikseret $i$ et hændelsesforløb, som har en påfaldende topografisk karakter. Kræften forvandles derved til et sted, man kan rejse ind i og ud af igen (Gibbs, Jr. \& Franks, 2002). Den konventionelle kræftrejsefortælling stedfæster dermed det ønskværdige forløb af sygdommen, idet den rejsende beskrives som én, der 'dykker ned' og dernæst 'stiger op', først er 'inde i' og efterfølgende 'ude igen'. Rejsemetaforikkens og rejsefortællingens topografiske tendenser underbygger nemlig forestillingen om, at den syge rejsende bevæger sig væk fra og derfor når ud 'på den anden side' af sygdommen. Ved afslutningen af rejsen positionerer den rejsende sig altid i god afstand fra det kaos, som præger 'sygdommens sted'.

Den klassiske ridderfærd, questen, er den litterære genre, som opmærksomheden ofte henledes på i sygdomssammenhæng, og som næsten har fået rollen som arketype for sygdoms- og kræftrejsen. Således udgør questen den ene af de tre hovedgenrer, som sociologen Arthur Frank udpeger i sin navnkundige genreteori over selvbiografiske bogpublicerede sygdomsfortællinger²:

Quest stories meet suffering head on; they accept illness and seek to use it. Illness is the occasion of a journey that becomes a quest. What is quested for may never be wholly clear, but the quest is defined by the ill person's belief that something is to be gained through the experience. (Frank, 1995).

Et af sygdoms-questens mest iøjnefaldende kendetegn er, at den rejsende ofte iscenesættes som en helt, der kæmper en kamp mod sygdommen og ved sin styrke, udholdenhed og kløgt overvinder sygdommen og alle dens forhindringer og vender hjem som en sejrsherre (Segal, 2007). Den konventionelle kræftrejsefortælling er således ikke alene nært beslægtet med questens, komediens og 
romancens masterplots, der foreskriver en 'happy end ${ }^{\prime 3}$, men trækker ofte på den krigsmetaforik, som Susan Sontags monumentale kritik af den kulturelle anvendelse af sygdomsmetaforer oprindeligt satte på landkortet (Sontag, 1989), og som forskningen sidenhen har studeret i relation til kræftens mangfoldige kulturelle repræsentationer (Garrison, 2007; Penson, Schapira, Daniels, Chabner \& Lynch, Jr., 2004; Reisfield \& Wilson, 2004; Teucher, 2003). Konventionelle kræftrejsefortællinger indskriver sig således ofte i den metaforik, som præger såkaldte 'cancer heroics' (Seale, 2002; Segal, 2007) og 'cultural stories of triumph' (Conway, 2007; Ehrenreich, 2009):

Those who write a triumph narrative, even while depicting the devastating events of illness or acci-dent, tend to represent the self as stable and robust and therefore able to battle disease and maintain a positive attitude while doing so." (Conway, 2007) $)^{4}$.

Helte- og triumf-narrativernes konventioner involverer netop ikke alene en særlig opfattelse af sygdommen, som noget der skal bekæmpes og overvindes, men også en særlig opfattelse af selvet som en stabil eller uforanderlig enhed, der enten går upåvirket igennem eller tilmed kommer styrket ud på den anden side af rejsen (Sandaunet, 2008; Seale, 2002; Segal, 2007).

Metaforiseringen af kræft er uomtvistelig (Ehrenreich, 2009; Sontag, 1989; Stacey, 1997). Dele af den danske og udenlandske selvbiografiske kræftlitteratur eksponerer og tematiserer nødvendigheden af og behovet for at metaforisere sygdommen for at håndtere den (eks. (Broyard, 1992; Flyvholm, 2008; Lorde, 1980; Nielsen, 1999). Ligeledes beskæftiger dele af forskningslitteraturen sig med de tilsigtede positive effekter af metaforiseringen, eksempelvis af at inddrage metaforerne i kommunikationen i kræftpraksis (Casarett, Pickard, Fishman, Alexander, Arnold, Pollak et al. 2010; Fawcett, 2011; Harrington, 2012; Skott, 2002).

Den konventionelle kræftrejsemetaforik favoriserer dog en særlig måde at anskue og fortælle sygdommen på, som har sine åbenlyse svagheder og begrænsninger (Koch, 2008). De består blandt andet af den mere eller mindre eksplicitte tilsidesættelse af sygdommens eksistentielle skyggesider, herunder af hvordan kræft ikke bare forstyrrer, men til tider nedbryder identitet og ikke mindst den rolle, som døden spiller som en særdeles nærværende realitet i mange menneskers liv med kræft. I sin traditionelle udformning er kræftrejsefortællingen i risiko for at undertrykke og hindre fortællingen af det, der er anderledes, og som falder udenfor rejsens norm og destination, som fortællingen enten undviger eller overdøver. Således indskriver fortællingen om 'kræften som en rejse' sig i diskursen omkring 
det 'socialt acceptable', der er bestemmende for, hvordan kræftsygdomme typisk fortælles (Broom, 2001; Conway, 2007; Ehrenreich, 2009; Sandaunet, 2008). Den er ikke alene i besiddelse af forunderlige konnotationer af både eventyr og ferie, men medvirker til at sløre de kaotiske, ulykkelige, sorgfulde og uberegnelige aspekter af livet med kræft, foruden at den netop også foregiver muligheden for i det hele taget at udføre en konsekvent målstyring af både sygdom og tilværelse. Den konventionelle kræftrejsefortælling byder sig dermed til som en del af den restitutions- og quest-diskurs (Frank, 1995), der til tider er bærer af en om ikke en bevidst tilsløring af, så en indirekte mangel på anerkendelse af den frygt og det tab af kontrol og af liv, som kræftsygdomme har potentiale til at påføre et menneskeliv.

Gennem inddragelsen af litteraturteori, der beskæftiger sig med litteraturens fremstilling af tid og rum, og med rejsen, undersøger jeg de tider og steder og den rejse, som den udvalgte fortælling kortlægger og tematiserer. Mit formål er at vise, hvordan det ser ud, og hvad det betyder, når kræftrejsen ikke udfoldes i henhold til idealet for den konventionelle kronologiske og målstyrede rejse. Således vil min analyse vise, hvilke narrative, identitetsmæssige og eksistentielle implikationer det har, når forfatteren stiller lineære opfattelser af tid, sted og identitet og af rejsen i tvivl og manifesterer det, som jeg betegner som en kronotopisk dislokation af tid, sted, fortælling og identitet, og af rejsen. Forfatteren er en usædvanlig rejsende og fremviser en måde at bevæge sig igennem sygdomsforløbet på, som adskiller sig radikalt fra questens triumferende heltefortælling.

Jeg ønsker derved at bidrage til at udfordre vanlige forståelser af relationer mellem kræft, tid og identitet, der er knyttet til anskuelsen af kræften som en rejse, som er beslægtet med det tankesæt, der er indlejret i begrebet om en narrativ identitet (Brockmeier \& Carbaugh, 2001; Ricoeur, 1985; Tygstrup, 2000). Således er min analyse også rettet mod at diskutere det betydningsbærende spændingsfelt, som fortællingen skaber mellem en kronotopisk og en narrativ identitet.

\section{Metode og teoretisk ramme}

Analysen er inspireret af case-analysens metode (Flyvbjerg, 2006) og udgør et forsøg på at 'tænke med fortællinger' (Frank, 1995). Casen er ikke repræsentativ i den forstand, at den indkredser almene tendenser, som generelt er gældende i gruppen af danske kræftselvbiografier. Den udvalgte case er tværtimod 'ekstrem', det vil sige atypisk, usædvanlig og afvigende og dermed i Flyvbjergs forstand 'paradigmatisk' (Flyvbjerg, 2006). Selvbiografien optræder således som 'en åbning i det 
givne og selvfølgelige, som det i sagens natur er vanskeligt at få øje på’ (Bech-Jørgensen, 2002) og anvendes i denne sammenhæng til at rejse en særlig problematik. Case-analysen optræder både som en analysestrategi og en formidlingsstrategi, der lader den enkelte forfatter komme udførligt til orde.

Jeg baserer analysen på en dobbeltrettet ontologisk anskuelse af den selvbiografiske kræftfortælling som et fuldgyldigt personligt vidnesbyrd om livet med en kræftsygdom og som æstetisk litterært objekt (Henriksen, 2011; Henriksen, Tjornhoj-Thomsen \& Hansen, 2011). I den forstand anvender jeg både fortællingen som dokumentar om livet med kræft, der refererer til og repræsenterer livet med kræft, og som fiktion, der skaber sit eget litterære univers og sin egen imaginærtæstetiske fortælling om sygdommen, som sideløbende indlejrer og repræsenterer almene kulturelle, litterært-æstetiske forestillinger.

Analysen inddrager litteraturvidenskabelig metode og teori. Den er overordnet set inspireret af den topografiske litteraturlæsnings metoder og teorier (Bakhtin, 1982; Miller, 1995; Tygstrup, 2001) såvel som af fænomenologiens rumlige poetikker og æstetisk topografiske tænkning (Bachelard, 1958; De certeau, 1978; Ströker, 1977). Disse metoder og teorier er båret af den særlige erkendelsesinteresse, som vedrører, hvordan litteraturen repræsenterer, beskriver, fortæller og skaber tid og rum, og hvordan det fysiske rum erfares, fortælles og skematiseres litterært, poetisk og æstetisk. I analysen inddrager jeg specifikt den russiske litteraturteoretiker M.M. Bakhtins begreb om kronotopen i romanen (Bakhtin, 1982), samt Frederik Tygstrups Bakhtin-inspirerede begreb om den kronotopiske identitet (Tygstrup, 2000), idet jeg introducerer sidstnævnte i tilknytning til analysen.

\section{Kronotopen}

Bakhtin indfører begrebet om kronotopen i sin romanteori for at belyse, hvordan forholdet mellem tid og rum gestaltes i romangenren. Kronotopens betegnelse er sammensat af de græske ord kronos (tid) og topos (sted) og karakteriseres altså som det spatio-temporale matriks, der former romanen:

They are the organizing centers for the fundamental narrative events of the novel.

The chronotope is the place where the knots of narrative are tied and untied. It can bed said without qualification that to them belongs the meaning that shapes narrative. (Bakhtin, 1982).

For Bakhtin udgør kronotoperne de betydningsmæssige mest centrale knudepunkter i romangenren (Bruhn, 2005b), som ofte optræder i konstellationer af flere 
samtidigt eksisterende kronotoper, hvilket hænger sammen med romangenrens heteroglossia, dvs. dens mangesidighed. I kronotop-essayet indkredser Bakhtin flere navngivne litterære kronotoper, såsom 'idyllens kronotop' og 'den rabeleske kronotop', som jeg introducerer nærmere i analysen (Bakhtin, 1982). De enkelte kronotoper svarer til genrer, som hver især skematiserer et særligt tidsrum og udtrykker en særlig anskuelse af verden, som romanen sætter i dialog med hinanden.

Men ydermere anfører Bakhtin, at sproget i sig selv er kronotopisk, og at alle former for betydning er kronotopisk, og han ophøjer kronotopen til at være intet mindre end selve 'det centrale ordnende princip for livet' (Peeren, 2008). Således rækker kronotopen videre ud end roman- og genreteorien ind i Bakhtins sprogfilosofi. Kronotopen er altså ikke alene bundet til aflejringen af specifikke historiske kronotoper/genrer og til indvævningen af genrens fiber i sin skematiserende aktivitet i den litterært æstetiske formgivning, men hæver sig samtidig over litterære og genrespecifikke former, som en almen sproglig funktion, et sprogligt nøgleregister (Bruhn, 2005b; Tygstrup, 1999). Kronotopen anskues som en sprogets krumtap, som et basalt sprogligt princip, der skematiserer tid og rum og derved skaber forbindelser mellem sprog og verden. Således har begrebet karakter som et repræsentationsteoretisk nøglebegreb hos Bakhtin, hvis almene bestemmelse borger for at inddrage det $\mathrm{i}$ analyser af forskellige typer af litteratur, herunder af forskellige typer af kulturelle handlinger og repræsentationer.

Perspektiverne for min egen analytiske anvendelse af begrebet er flere. Jeg tager afsæt $\mathrm{i}$ at anvende kronotopen som et tekstanalytisk værktøj, idet jeg løbende identificerer og navngiver de kronotoper, der konstituerer selvbiografiens steder og tidsrum, som jeg sideløbende relaterer til udvalgte historiske kronotoper, som omtales i Bakhtins essay. Den topografisk inspirerede litteraturteoretiske indfaldsvinkel udgør hovedbestanddelen i analysen af selvbiografiens tider, steder og rum, såvel som af dens metaforik. Derudover inddrager jeg litteraturfilosofiske refleksioner, som har til hensigt at perspektivere betydningen af kræftfortællingens etablering af rejsen som kronotop og den kronotopiske identitet, med henblik på at uddybe de eksistentielle, narrative og identitetsmæssige relationer og implikationer, som selvbiografiens tidslige og topografiske forhold fremskriver og udfolder. 


\section{Kræftrejsen, den eksistentielle hjemløshed og den kronotopiske identitet}

\section{Liselotte Vendelboe Andersen ${ }^{5}$ : Vingefang (2008)}

Vingefang er udgivet som bog på eget forlag. Forfatteren Liselotte Vendelboe Andersen er 41 år gammel, da hun udgiver bogen. Hun er fraskilt mor til tre døtre, hvoraf den yngste er syv år gammel. Hun har været syg af brystkræft i fire år, har fået fjernet begge bryster og har været i strålebehandling og kemoterapi. Hun er erklæret uhelbredeligt syg af brystkræften, som har spredt sig til lymfekirtlerne, og hun modtager livsforlængende kemobehandling.

Vingefang optræder ikke som en specifik beskrivelse af sygdomsforløbet, endsige som en rendyrket sygdomsberetning, men snarere som en fortælling om forfatterens gennemgribende eksistentielle fortvivlelse. Forfatteren tematiserer, hvordan det er at befinde sig tæt på døden og det, der for hende føles som at leve i eksistentielt tomrum. Liselotte V. Andersen er vidende om, at hun indenfor en årrække skal dø fra sine tre børn, som hun bor alene med. Hendes familiære omstændigheder er belastede, idet både hendes fraskilte mand, som forlod hende, da hun blev syg, og den øvrige familie har svigtet hende. Den eksistentielle fortvivlelse er en tematisk drivkraft i fortællingen, som samtidig gennemtrænger fortællingen på et formmæssigt plan.

Således er bogen struktureret som en samling af a-kronologiske øjebliksbeskrivelser og refleksioner. Fortællingen springer i tid og fremtræder som en montage af brudstykker af små følelsesmættede scener og begivenheder i forfatterens liv. Bogens form underbygger dermed læserens indtryk af forfatterens fortvivlelse. Fortællingen skaber et handlingsgenererende spændingsfelt mellem forfatterens overlegne litterære kontrol og leg med den narrative form og den sideløbende tematisering af de tab og det fravær, som kræftsygdommen medfører, der netop også relateres til et tab af sprog, form og fortælling. På mesterlig vis lykkes det forfatteren at håndgribeliggøre et gennemgribende eksistentielt fravær, som knytter sig til kræftens univers ved at kortlægge det, der umiddelbart fremstår som et eksistentielt ødeland. 


\section{Barndomskronotopen, den nedbrudte idyl og den eksistentielle hjemløshed}

I tilknytning til forfatterens overvejelser om hvordan kræften påvirker hendes forestillinger om tid og identitet, inddrager hun overvejelser om sin traumatiske barndom. Således optræder erindringen af fortiden som ét af selvbiografiens mest iøjnefaldende træk, der underbygges af forfatterens lige så iøjnefaldende anvendelse af stedslige metaforer og af den sceniske fremstillings teknik. Forfatteren mestrer den sceniske fremstilling til perfektion, hvilket hensætter læseren i tilbageblikkets og genoplevelsens rå virkelighed, som knytter sig til de svigt, som hun oplevede i sin barndom, som her hvor hun beskriver følelsen af, hvordan det er at blive efterladt alene hjemme, bare 3 år gammel:

Jeg er alene hjemme hver morgen, når mor kører min storesøster i skole. Jeg står bag gardinet. Eller gemmer mig under det store egetræsskrivebord. Jeg holder vejret. Jeg venter. Venter på mor. Venter på, at hun kalder på mig. Hun må da kalde på mig. Jeg har været alene hjemme. Hun må da have savnet mig. ... til sidst er det ikke længere til at bære. Jeg lister frem fra mit selvvalgte skjul. (p. 69)

Barndommens kronotopicitet bryder vedvarende ind i fortællingen om nutiden og dermed i fortællingen om livet med kræft. Barndommen har frataget forfatteren trygheden, bragt hende ud af sig selv og skabt en følelse af, at hun så at sige altid føler sig 'alene hjemme'. Forfatterens manglende selvfølelse accentueres af kræftsygdommen, men den kædes vedvarende sammen med barndommens omsorgssvigt. Kræftsygdommen fremkalder altså følelser og stemninger, som trækker fortidens smertefulde fortælling ind i nutidens fortælling om kræften:

$\mathrm{Nu}$ står jeg her midt i mit liv og føler ikke at jeg hører til nogen steder. Igen. Har jeg nogensinde følt at jeg hørte til nogen steder? Kræften har vækket disse grundfølelser i mig igen. Grundstemningerne. Vækket sorgen over at føle sig svigtet og valgt fra (p. 70)

Hjemløsheden og den manglende selvfølelse eksponeres af livet med kræften og af den kræftopererede krop, men peger hele tiden tilbage mod fortiden, helt konkret mod barndommens verden:

Jeg føler mig fristet til at overgive mig til mørket. ... opgive at stride mig vej ind til det, jeg tror, er mig selv. Det mig som jeg ikke har lært at udfolde hjemmefra. (p. 37). 
Barndommen sætter altså sit kronotopiske spor i fortællingen igennem aftegningen af et særligt tidsrum, der ikke alene håndgribeliggør en fortidig verden, men netop også stedfæester et traume og det oprindelige udspring af den store sorg og grundlæggende ensomhed, der præger forfatterens fortælling om sin tilværelse med kræften.

Barndomskronotopen markerer således etableringen af en anderledes udgave af den idylliske kronotop, som Bakhtin indkredser (Bakhtin, 1982). I ældre tiders litteratur var idyllen en lyrisk-episk genre, der i idealiseret form skildrede menneskets liv i harmoni med naturen. I ro-manen tematiseres den idylliske tilstand derimod, som noget der er tabt og per definition ikke kan reetableres. Idyllen bliver derfor en uopnåelig tilstand med paradisiske træk, der får karakter som en utopi. Den hovedperson, som søger idyllen, må se sig selv udstødt af den, og denne udstødelse og tiden derefter er netop det, handlingen drejer sig om. Således bliver idyllen ofte anvendt $i$ et tematisk bærende topografisk modsætningsforhold mellem et fortidigt og et nutidigt topos, idet sidstnævnte indskriver en længsel efter det svundne i romanen. Romanen opstår groft sagt på baggrund af idyllens nedbrydning og den deraf følgende længsel efter det tabte, der netop er indbegrebet af det trygge barndomshjem og en harmonisk barndom.

Her er idyllens kronotop forvandlet til en eksplicit nedbrudt og perverteret idyl, der står som en grel modsætning til et trygt barndomshjem og en harmonisk barndom. Selvom forfatteren ikke anlægger en nostalgisk tilværelsestolkning, der indbefatter en længsel efter en svunden tid, konstitueres selvbiografien i høj grad af de afsavn, som knytter sig til hendes barndom, som hun genoplever i livet med kræft. Barndommens kronotopicitet medvirker netop til at indkredse og kortlægge den basale eksistentielle hjemløshed, som kendetegner kræftens verden. De mangler, som forfatteren bærer med sig fra barndommen, genaktualiseres af kræfterfaringen og synliggøres uophørligt gennem inddragelsen af hjemløshedens topografiske metaforer:

Det er som om hjemme ikke findes, når kræften på den måde trænger sig på, som den gør i mit liv. ... Kræften invaderer min krop, der ikke længere føles hjemlig. (p. 22) .

Som det fremgår, spejler den eksistentielle hjemløshed sig i den ultimative kropslige hjemløshed, der følger med den dobbelte brystfjernelse. Når forfatteren henviser til brystfjernelsen, betegner hun konkret sig selv som værende 'hjemløs i sin egen krop' (p. 79), og hun tematiserer i den forbindelse betydningen af den freudianske term 'unheimlich', der både vedrører det uhyggelige og det $i k$ - 
ke-hjemlige $e^{7}$ Den dobbelte brystfjernelse optræder både som moderløshedens og hjemløshedens mærke på kroppen. Den er et semiotisk mærke med eksistentiel betydning (Henriksen \& Hansen, 2009), der simultant betegner det, forfatteren selv manglede som barn i form af tryghed og omsorg fra en mor, og den frygt hun har for at gøre sine egne børn moderløse og dermed hjemløse, som følge af sin forestående død. Den brystløse krop og brystfjernelsens mærke på kroppen tegnsætter dog ikke alene de ultimative tab, som kendetegner barndomsliv og kræftliv, men inkarnerer så at sige selvbiografiens samlede eksistentielle tabsfortælling. Selvbiografien anvender figuren 'semiotiseringen af kroppen - somatiseringen af teksten' (Brooks, 1993), som tager afsæt i at stedfæste kræftens udspring i kroppen, men løbende forvandler kroppen til et af fortællingens steder, iklædt en egen topografi og en egen 'stedets skrift'. Beskrivelsen af og fortællingen om den brystopererede og kræftbehandlede krop har således karakter som et centralt topos i selvbiografiens litterære univers, der tilmed er bærer af en specifik kronotopicitet og et særegent sprog.

\section{Den karnevalistiske kræftkrop og den rabeleske kronotop}

Forfatterens brystopererede, kemo- og strålebehandlede krop optræder som et karnevalistisk topos i fortællingen. Den karnevalistiske krop udgør kernen i den rabeleske kronotop, som Bakhtin definerer med forlæg i den franske 1500-tals forfatter Francois Rabelais' eventyrligt groteske og komiske episke fortællinger om kæmperne Gargantua og Pantagruel (Bakhtin, 1982; Bakhtin, 1984b). Den rabeleske kronotop er således funderet i det middelalderlige karnevals kropslige vulgære udskejelser, udladninger og overdrivelser, som kommer til udtryk gennem kroppens åbninger og eksponeringer, der fremviser det skjulte og private, det der ifølge decorum ellers er forbudt at fremvise (Bruhn, 2005a). Den karnevalistiske krop kan læses som et stumt sprog, der udkrænger tilværelsens uudsigelige og groteske aspekter, og derved bringer dem op til overfladen som et underliggende ubevidste, der udfordrer autoriteten og loven (Kristeva, 1986).

Forfatterens kræftbehandlede krop er som karnevalskroppen præget af obskøne overdrivelser, udladninger og udkrængninger (Bakhtin, 1982). Kræftkroppen er på karnevalistisk vis gået amok som en talende krop, og forfatteren beskriver udførligt, hvordan den brystopererede krop er plaget af bivirkninger fra kemoog strålebehandling, hvordan den bløder ud af næsen, taber sit hår, sveder, går i overgangsalderen, kaster op, etc. og kroppen understreges flere gange som en overvxgtig krop. Den brystløse og arrede krop er netop indbegrebet af den åbne 
og eksponerende karnevalistiske krop, som stumt gestikulerer forfaldet, sorgen og døden.

Den groteske karnevalistiske krop optræder side om side med barndommens kronotop, som den vedvarende går i dialog med og medvirker til at fremhæve den eksistentielle hjemløshed og forfatterens manglende selvværd. Således suppleres etableringen af barndomskronotopen og kroppens rabeleske kronotop med anvendelsen af en lignende hjemløsheds-terminologi:

Igen føles det som om jeg bevæger mig udenfor det 'normale'. Ved siden af. De normale er alle de andre. Jeg er den forkerte. ... Det handler om, at jeg ikke føler at jeg er med i mit eget liv. Eller livet i en mere generel forstand. At jeg er blevet kørt ind på et sidespor. Jeg er nu - igen - slået ind på en vej, der fører mig steder hen, jeg ikke ønsker at befinde mig. Steder hvor der er mørkt og ensomt. ... At have kræft, at skulle leve med kræft hele tiden, har bragt mig ud på en slags sidespor i tilværelsen. Som om jeg er her på lånt tid. ... (p. 70-71).

Kræften medvirker på linje med erindringen af barndommen til at føre forfatteren ud på et sidespor i tilværelsen, et mørkt og ensomt sted med en særlig topografi:

For mig er kræften sort og dyster. Som et stykke dødt landskab, hvor alt er afsvedet.

Goldt. Ørkesløst. Livløst (p. 34).

Fortællingens særlige topografiske perspektiv på livet med kræft skaber ikke alene en dialog mellem fortid, nutid og fremtid, men også mellem en ydre og en indre topografi, og de to spejler sig i hinanden. Forfatteren fremskriver og visualiserer fraværet af selvfølelse som et kropsligt fravær og som et fravær af stedfølelse. Som den karnevalistiske krop, der i kraft af sine udskejelser og verdensvendte eksponering, udvisker skellet mellem subjektet og verden (Bruhn, 2005b; Lock, 2001), udvisker fortællingens topografi skellet mellem selv, sted og krop og mellem fortid, nutid og fremtid. Den kronotopisk-topografiske ophobning af hjemløshedens emotionelle geografi spreder sig dermed som grundstemning, der spejler sig i forfatterens tematiseringer af kroppens karnevalistiske ukontrollerede amokløb og et fravær af selvværd, samt i selvbiografiens generelle formmæssige opbrud. Fraværet af hjemlighed rumliggøres netop af den vedvarende kronotopiske dialog mellem varierende, men samtidig beslægtede tidslige, rumlige, kropslige og følelsesmæssige tilstande, hvilket medvirker til at give læseren et overordnet indtryk af, at forfatteren basalt set aldrig føler sig 'helt hjemme', aldrig kan finde 
ro og altid er ude af sig selv, men samtidig er fastlåst i sin fortsatte recitation af barndommens, kræftens og kroppens traumer.

\section{Non-lineær, flerdimensionel, multi-temporal dialogisk topografisk kompleksitet}

Selvbiografien udvikler en særlig tidslig og rumlig fortælling om livet med kræft, der er alt andet end lineær. Destabiliseringen af den kronologisk lineære fremadskridende fortælling markeres gennem de kronotopiske spring i tid, som sætter fortiden i dialog med nutiden. Hos læseren afstedkommer det en klaustrofobisk følelse af stilstand, af at fortællingen reelt ikke bevæger sig ud af stedet, men tværtimod vedvarende næsten bogstaveligt går på stedet eller i ring. Alene i kraft af barndommens massive kronotopiske indflydelse, bliver læseren opmærksom på eksistensen af en temporal, eksistentiel og identitetsmæssig kompleksitet i forfatterens liv, som ganske udelukker en lineær model for fortællingen. Etableringen af barndomskronotopen underbygger således den gennemgribende indflydelse, som kræftsygdommen har på forfatterens tilværelse, som en tilstand der foranlediger uophørlige genoplevelser af barndommen.

Kronotopiciteten medvirker til at konstituere fortællingen som værende præget af en gennemgribende dialogisk destabilisering (Bakhtin, 1984a; Frank, 2000). Fortællingen former sig som en dialog mellem forskellige tiders og steders perspektiver og positioner. Forfatteren taler netop ikke kun om barndommen og kræften, hun taler i høj grad fra barndommens og kræftens tider, som værende forankret i de specifikke steder og positioner. Via den sceniske fremstilling fortælles barndommen af og med barnets stemme og som set fra barnets perspektiv. Det samme gælder fortællingen af kræften, som netop ikke er en fortælling om kræften, idet forfatteren fortæller som værende forankret i sygdomserfaringsprocessen, ikke på afstand af den. På den måde rykker det fortalte helt tæt på erfaringen og dermed helt tæt på læseren. Det er ikke monologiske, autoriserede og færdigformede erfaringer, som berettes hinsides fortvivlelsen og lidelsen, der serveres for læseren, men erfaringer, som er undervejs til at blive gjort og som hele tiden gøres på ny, mens de fortælles.

Forfatterens identitetskrise materialiserer sig igennem fortællingens basale kronotopicitet, dvs. i mødet mellem barndomshjemmets verden og kræftens verden. Hjemløshedens kronotopiske og kropslige træk er således meget stærkt tilstede i den måde, hvorpå forfatteren tematiserer sin identitet, og i en grad hvor der 
netop er tale om manifestationen af en specifik kronotopisk identitet, som yderligere specificeres i den måde, hvorpå rejsen ligeledes etableres som en af selvbiografiens kronotoper.

\section{Rejsens kronotop, tærsklen og den kronotopiske identitet: Hvor er jeg? Hoor er jeg på vej hen?}

Frederik Tygstrups begreb om den kronotopiske identitet tager afsæt i Bakhtins begreb og er udviklet i sammenhæng med en analyse af forfatteren Morten Søndergårds digtsamling Ubestemmelsessteder (Tygstrup, 2000). Tygstrup modstiller begrebet om den kronotopiske identitet med begrebet om en narrativ identitet. I modsætning til den narrative identitet er den kronotopiske identitet ikke beskæftiget med at svare på spørgsmålet om 'hvem er jeg?', men derimod 'hvor er jeg?'. Således defineres den kronotopiske identitet som en radikalt anderledes måde at tænke og fortælle selvet på, som står i opposition til forestillingen om en kronologisk-lineær identitet. Den kronotopiske identitet udfoldes som en udadvendt rumlig ageren, som et rastløst forsøg på at orientere sig i rum, der samtidig er kendetegnet ved at være tøvende og prøvende og som værende blottet for sikker stedfæstelse og stedsans.

Læseren fornemmer løbende, hvordan forfatteren foregiver at ville svare på spørgsmålet om 'hvem er jeg?', men ved uophørligt at stille spørgsmålet 'hvor er jeg?'. Forfatteren forbinder netop sin rastløse og hjemløse færden med en forståelse af identiteten, som er sammenlignelig med den kronotopiske identitet. Og denne rastløse identitetsmæssige topografiske eftersøgning underbygges af forfatterens iøjnefaldende inddragelse af rejsen i selvets kronotopiske fortælling.

Rejsen optræder ikke bare som metafor og tema, men netop som en kronotop, som fungerer som en bærende krumtap i selvbiografiens fremstilling af tid og rum, der medvirker til at give fortællingen sit umiskendelige genrepræg som rejsefortælling, der samtidig vedvarende udfoldes som en ukonventionel rejsefortælling.

Forfatteren drømmer om at rejse og beskriver konkret sig selv som en rejsende:

En nat drømmer jeg igen om stationer, og lufthavne og baggage, og hvor skal jeg hen, hvor skal jeg sove. Som natten før. Hvor jeg drømte, jeg gik fra station til station, og måtte spørge en sort mand om vej, og han pegede mod en station og forklarede mig, hvordan jeg skulle komme til min destination... Jeg vågner og er forvirret. 
Som om jeg hele natten har stæset rundt og ledt efter en vej mod mit mål. Jeg aner ikke hvad min destination er. (p. 80).

Den rejsende er altså faret vild og kan ikke finde sin destination. Men hun er også rejsende i den anden forstand, at hun søger rejsens eventyr og fra tid til anden tillader sig at drømme sig væk: 'Så snart mørket indimellem løfter sig en anelse fra mit sind vælder trangen til eventyr op i mig' (p. 81), hun har udlængsel og vil gerne 'være opdagelsesrejsende' (p. 82).

Samtidig forsøger hun at tøjle sin udlængsel og netop for at skabe det hjem for sine egne børn, som hun selv manglede som barn:

"Jeg kan ikke bare rykke teltpælene op sammen med mit rastløse sind, ud og søge nye horisonter. ... Mine børn vil jeg godt skåne for denne rastløshed. Jeg vil godt give dem et sted, hvor de hører hjemme. (p. 93).

Hun er på én gang fastlåst i tid og rum, dvs. i de tider og steder, som kræftens og barndommens kronotoper i fællesskab fremmaner og oppebærer, og samtidig er hun uden forankring i tid og rum. Fremfor alt ønsker forfatteren at flytte sig væk fra nu'et, at flygte fra de vilkår, som sygdommen og barndommen har påtvunget hende:

Nuet kræver min opmærksomhed. Kræften har frataget mig fornemmelsen af uendelig tid. 'I morgen', bliver pludselig en frase, der skræmmer. Hvad gemmer morgendagen? Kommer morgendagen overhovedet? For mig? Jeg vil helst løbe min vej, videre, væk fra det nu, jeg fornemmer, og som jeg ikke ønsker at dvæle for meget ved. Lad det blive hverdag igen, tænker jeg med en snigende klaustrofobisk følelse i mellemgulvet. Dette syn af udstrakte nu'er virker truende. ... Jeg har alle dage været på vej væk i strakt galop fra nuet. Væk fra øjeblikket. ... Nu er fyldt med sorg. ... Nu er at være fanget og uden bevægelighed. (p. 73-74).

Nuet trænger sig på. Kræften har spændt ben for mig. Jeg er i frit fald. Bevægelsen fremad, videre, hurtigt, gennem dagene, gennem tilværelsen, stopper brat. Jeg tvinges til at stoppe op. Stå stille. En stund. Betragte hvor jeg befinder mig. Midt i tilværelsen. Midt i min tilværelse. Midt i mit liv. Ja men hvor er jeg? Jeg kan ikke finde mig selv. (p. 73).

Forfatteren er indbegrebet af det permanent hjemløse og rodløse menneske og kobler vedvarende sin identitetsspecifikke krise til overvejelser over, hvor hun befinder sig i tid og rum: "Hvor er jeg henne? hvor var jeg før? ... Måske dukker der 
nye landskaber op i horisonten" (p. 11). På kronotopisk vis eftersøger hun en stedfæstelse af og en retning for sit selv, men som hun også siger: "Jeg har svært ved at finde en retning for mig selv". (p. 21). Forfatteren er netop ikke prototypen på den konventionelle kræftrejsende, der bevæger sig frem mod et veldefineret mål af lineær vej. Hun befinder sig i en fritsvævende målløs tilstand uden fremdrift, i en både rastløs og fastlåst tilstand, der til forveksling minder om tilstanden af at befinde sig i det tærsklens kronotop, som Bakhtin beskriver, som følger:

Its most fundamental instance is as the chronotope of crisis and break in life. ... in this chronotope time is essentially instantaneous; it is as if it has no duration and falls out of the normal course of bio-graphical time. (Bakhtin, 1982).

Modsat quest-heltens selvbevidste rejse tegner forfatterens rejse et billede af selvet som værende ude af sig selv, sat udenfor tid og sted, i en tærskeltilstand, hvor hun er uden mulighed for reelt at påvirke tilværelsens, sygdommens og rejsens retning.

I sit kronotop-essay beskæftiger Bakhtin sig også med det, han kalder vejens kronotop. I en sammenligning med den måde hvorpå vejens kronotop udfoldes i veletablerede litterære rejser (som Bakhtin lokaliserer i adskillige navngivne quests, middelalderlige romancer og i dannelsesromanen, altså i genrer, der alle konstitueres af rejsen) (Bakhtin, 1982), pp. 243-245), som en specifikt velkendt vej, der tilbagelægges af helte, der ikke mærkes under rejsen (Gemzøe, 2003), udfører denne udtalt mærkede fortæller prøvende sonderinger på en vej, der på overfladen er ukendt. Samtidig åbenbares det dog langsomt for læseren, at forfatteren meget længe har været undervejs på sin ufrivillige rejse, og at rejsen blev påbegyndt meget tidligt $i$ hendes liv, men aldrig er afsluttet og derfor aldrig har nået sin endestation. Rejsen udføres altså i et landskab, der allerede er forsøgt kortlagt et utal af gange og derfor reelt ikke er fremmed. Rejsens kronotop, dens særlige tidsrum, der er fastlåst i en ekstrem form for nutid, fremmaner og formidler i den forstand en forbindelse mellem barndommens kronotopiske eksistentielle og emotionelle landskab og kræftens kronotopiske eksistentielle og emotionelle landskab

Esther Peeren har udpeget den kronotopiske identitet som 'et undereksponeret aspekt af identitetskonstruktionen', som vedrører identitetens 'spatiotemporale specificitet og situerethed' (Peeren, 2008). Peeren forklarer, hvordan 'tilhørsforholdet til stedet' ikke bare er afgørende for selvfølelsen, men simpelthen er det, der producerer identitet (Peeren, 2008). Sådan som Vingefang manifesterer identiteten, er der tale om en afart af den kronotopiske identitet, som Peeren definerer, der udfolder sig som en dialog mellem længslen efter at skabe et tilhørsforhold til stedet, 
at skabe et hjem og en tøvende, rastløst og ubestemmelig forholden sig, hvorved selve eftersøgningen af en destination, af et hjem og et tilhørssted smuldrer, og bliver afløst af rastløsheden og hjemløsheden.

Rejsen pointerer dog ikke alene relationer mellem barndomsliv og kræftliv, men peger også på betydningen af et særligt sted, et ubestemmeligt sted med en særegen topografi, som både fungerer som afsæt og destination for forfatterens rejse. Således er den non-lineære, multi-temporale og flerdimensionelle dialogisktopografiske kompleksitet, som selvbiografien fremmaner, også forbundet med den måde, hvorpå den etablerer et særligt udefinerbart sted som en (umulig) destination for rejsen.

\section{Ubestemmelsesstedets poetik}

I tilknytning til begrebet om den kronotopiske identitet udfolder Tygstrup betydningen af de narrative, identitets- og erkendelsesmæssige logikker, der henholdsvis kendetegner bestemmelsesstedet og ubestemmelsesstedet, som de udspiller sig i kunsten og i litteraturen (Tygstrup, 2000). Bestemmelsesstedet vedrører en særlig erkendelseslogik, som kendetegnes af en tidsopfattelse, der kan henføres til forestillingen om en narrativ identitet, for hvilken der gælder, at det er:

En historisk indflydelsesrig model for fiktionen, den taktfast fremadskridende fortælling, arrangeret $\mathrm{i}$ et meningsfuldt plot, styret og underlagt den handlende og målrettede subjektivitet, i en temporaliserende menneskeliggørelse af verden, som bevæger sig frem mod et mere eller mindre veldefineret mål. (Tygstrup, 2000).

U-bestemmelsesstedet vedrører derimod en identitetsmæssig erkendelseslogik, der kendetegnes af en rumlig tøven og en adspredthed, som netop henhører til forestillingen om den kronotopiske identitet. Tygstrup betegner u-bestemmelsesstedets logik som en udpræget modvilje mod at tænke verden i den individuelle udlægnings tidslige termer og modsat tænke individet i overvejende rumlige termer, som stiller bestemmelsesstedet i tvivl:

(Den) ubestemmer det der var en bestemmelse; et sted altså, der får den forud givne meningssammenhæng til at smuldre. Men netop ved at ubestemme denne sammenhæng, ikke ved at konfrontere den og stille et andet princip op mod den. (Tygstrup, 2000).

Bestemmelsessteder har denne dobbelthed, som både afsæt og som mål for rejsen. I dette tilfælde fornemmer læseren, hvordan forfatterens genfortælling af for- 
tiden optræder som et forsøg på at finde vejen frem ved at rette den op for derved at kunne redefinere målet for rejsen. Forfatteren udtrykker implicit en længsel efter at kunne konstruere en narrativ identitet, og hun søger, eller har tidligere søgt, et bestemmelsessted for at skabe en sammenhæng og en kronologi i sin historie:

Retning. Mangler mit liv en retning nu, hvor jeg er kræftramt? Skal mit liv overhovedet have en retning? Efter den første kræftdiagnose var jeg meget fokuseret på at 'komme om på den anden side'. (p. 80).

Samtidig foretager fortællingen et opgør med denne måde at organisere liv, fortælling og identitet på. Forfatteren gør op med bestemmelsesstedets logik som en gangbar måde at ordne og anskue identitet og tilværelse på, mere end hun forsøger at definere eller rekonstruere sin identitet og tilværelse.

Hendes fortælling handler om vedvarende at u-bestemme, en forud given forestillet bestemmelse, ved fortsat at stille selvsamme bestemmelse i tvivl. Forfatteren har mistet sit bestemmelsessted, sin destination eller rettere sagt måske aldrig været i besiddelse af det. På den ene side længes hun efter bestemmelsen, efter at kunne definere sig selv og sit bestemmelsessted. På den anden side udfolder hun en særdeles tydelig og intenderet ubestemmelse af identitet, tid og sted. Forfatterens identitet søges netop ikke rekonstrueret. Den udfoldes snarere i spændingsfeltet mellem forestillingerne om henholdsvis en narrativ og en kronotopisk identitet, som derved sættes i dialog med hinanden.

Kræftfortælleren befinder sig i en særlig tvivlende tærskeltilstand af at være dislokeret og sat udenfor tid og sted. Med sine egne ord befinder hun sig i "sådan en slags mellemting mellem liv og død" (p. 81). Tygstrup forklarer, hvordan den kronotopiske identitet udfolder sig i samspil med det såkaldt heterotopiske sted ${ }^{8}$, som er et sted: ".....uden forudgivne koordinater. Et sted som det ikke er muligt at begribe og analysere ved hjælp af koordinater, der er givet af instanser udenfor dette sted" (Tygstrup, 2000). Ubestemmelsesstedets topografi smelter sammen med forfatterens ubestemmelige identitet og hendes almene eksistentielle dislokation, der er forbundet med fremskrivningen af døden som et ubestemmeligt ikke-sted.

\section{'An excursion outside the plot proper' - rejsen mod dødens (u-) bestemmelsessted}

Som det fremgår, sætter forfatteren sin optagethed af tid i spil sammen med evigt tilbagevendende tanker om det ultimative ophør af tid, som døden truer hende 
med. Forfatteren er i høj grad beskæftiget med at bekræfte dødeligheden som en del af sit liv:

Skal jeg dø? Ja selvfølgelig skal jeg dø. Hvilket absurd spørgsmål. Men bliver det snart? Bliver det inden for de næste fem år måske? Eller før? Senere? For første gang trænger det helt ind i mit hoved. At jeg ikke skal leve evigt. (p. 29)

Hun indkredser døden, smager på den, tænker den og mediterer så at sige over den som et vilkår for sit liv, der via kræften er blevet tydeliggjort:

Når jeg før kunne være bange, for at dø, så var det mere abstrakt. Døden bliver virkelig. Den rykker ganske tæt på - og ja prikker mig skulderen. ... Døden er ikke bare en mulighed. Døden er en stor sandsynlighed, når jeg tænker på kræft. ... Døden bliver vitterlig virkelig nærværende og dominerende på en måde, som jeg bestemt ikke bryder mig om (p. 36).

Forestillingen om døden er det, som, i fællesskab med barndommens, kræftens og rejsens kronotoper, determinerer fortællingens tidsregning og rumlighed. Døden får eksistens som det store ophør af tid:

Jeg leder i min hukommelse. Leder efter min barndom. Leder efter min ungdom. Mit liv. Det bliver med et trukket helt tæt sammen og mast. Ligesom det truer med at slutte brat. Jeg vil helst strække det ud, mit liv. Strække det over lang tid og større rum. (p. 101).

Forfatteren tænker og skriver uophørligt om døden og tilnærmer sig den. Men samtidig skubber hun den foran sig og vægrer sig mod den, som et endemål hun bevidst forsøger at undgå at nå. Hun fastholder dødens u-bestemmelse af tilværelsens udstrækning som et eksistentielt grundvilkår og insisterer på at bevare den åbenhed, det bibringer hendes livsanskuelse og tilværelsestolkning:

Det er svært for mig at acceptere, at mit liv ikke har den udstrakthed, som jeg forventer det skal have. Men grænsen for mit liv vil jeg jo aldrig kende før den dag, jeg når den. På den led er kræften jo ligegyldig. Kræften viser mig vel blot, at mit liv netop ikke varer evigt (p. 81).

Døden får derved karakter som u-bestemmelsesstedet per se, som det bogstaveligt inkarnerede, ultimative bestemmelsessted, der samtidig er ganske umuligt at bestemme. Forestillingen om døden giver netop selvbiografien dens særlige resonans af u-bestemmelsesstedets logik. Den fremmaner et sted uden fysisk eksistens, et atopisk sted, dvs. et stedløst sted, der både er ingen steder og alle ste- 
der (Miller, 1995). Døden benævnes og forsøges fortalt, men kan ikke endegyldigt kortlægges, lokaliseres, fortælles eller defineres, hvilket underbygger den eksistentielle hjemløshed.

Liselotte Vendelboe Andersen står på tærsklen mellem liv og død. Hun befinder sig ved yderkanten af livet og sproget, i et eksistentielt og sprogligt randområde, og i en rolle som outsider, der på den ene side ønsker at være insider, ønsker at blive lukket ind i fællesskabet (helt konkret ind i sin egen familie, som har ekskluderet hende). På den anden side udlever hun rollen som outsider, som en slags alternativ identitet hun påtager sig at bære, en kronotopisk identitet for netop overhovedet at kunne være til. Forfatteren får eksistens i kraft af sin stadige søgen efter en tilværelse, som hun kan finde ud af at leve, og netop ikke bare overleve i. Og denne form for søgende, tøvende og eksperimenterende eksistens underbygges af den rolle, som selvbiografien selv spiller. Forfatteren peger på fortællingen som en modvægt til et manglende hjem, og som en funktion, der på en vis måde kan skabe den tryghed, hun savnede som barn, som netop var forbundet med et konkret afsavn af ord, sprog og fortælling:

Måske har jeg savnet ord i min opvækst, og netop derfor har jeg læst og lyttet meget til ord. Og selv skrevet ord. ... For at fortælle mig selv, hvordan jeg havde det. For at kunne definere mig selv som et individ. Hvis jeg var uden ord fandtes jeg måske slet ikke (p. 53).

Den kronotopiske fortælling betegner dog ikke alene den eksistentielle og identitetsmæssige hjemløshed, den omformer den. Selvbiografien har karakter som et rum for sansning af og refleksion over den ubestemmelse af tilværelse, tid og identitet, som barndommen og kræften har påført forfatteren. Den manglende fremtid og den manglende selvfølelse, som forfatteren har udsyn til, 'oversættes' vedvarende til en egen rumlighed og en egen selvfølelse, der således næsten optræder som erstatning for den manglende fremtid og den manglende selvfølelse. Den litterære topografi bliver i den forstand et modsvar til og et forsvar mod et manglende hjem og fremtidens truende ophør af tid.

Selvbiografiens kronotopicitet forankrer og fastholder det levede liv, som forfatteren ved, at hun før eller siden må give uigenkaldeligt afkald på. Sprogets og skriftens topografiske materialitet holder derved rejsens uigenkaldelige endemål i form af døden på afstand. Så længe forfatteren skriver, undgår hun netop den slutning på sin historie, der i forvejen står skrevet for hende, og som hendes rastløse skrivning, denne skriftrejse, skubber foran sig. I den forstand udfolder hendes skrift sig som 'et symptom på ikke at dø' (Stacey, 1997). 
Forfatterens skrivning modarbejder flere af de veletablerede konventioner og undergenrer, som eksisterer for den selvbiografiske kræftfortælling. Hun vil ikke fanges i de gængse kategoriseringer, hun insisterer på sin individualitet, ikke mindst som skrivende bevidsthed:

Jeg har ikke så meget forsøgt at skrive om, hvordan jeg håndterer livet med kræft.

Og jeg har ikke skrevet så meget om hvordan man kommer op på hesten igen...

Det er der så vidt jeg kan se skrevet mangt og meget om andre steder. Hvis du som

læser leder efter svar finder du dem ikke i denne bog (p. 7).

Hendes skriftrejse er i høj grad baseret på en forståelse af at være en mod-fortælling (Bamberg \& Andrews, 2004), der blandt andet næres ved at adskille sig fra den dominerende konventionelle kræftrejsegenre, som eksempelvis ofte præger selvhjælpsfortællingens handlingsanvisende undergenre (Henriksen, 2011). Forfatteren ekspliciterer, at hun ikke kan udpege en vej eller en alment gangbar forståelse af livet med sygdommen for andre:

Jeg har ikke set lyset. Vejen. Og hvis jeg havde, ville jeg holde den for mig selv. Der er nok prædikanter i verden. Og vi har alle vores vej at gå. Min vej ville ikke nødvendigvis være god for nogen andre (p. 93).

Som en karnevalsdeltager foretager Liselotte Vendelboe Andersen en "excursion outside the plot proper' (Bakhtin, 1982), p. 36), og hendes fortælling bryder effektivt plottet for den konventionelle lineære kræftrejse. Mens hun sideløbende fremskriver konturerne af en destination for rejsen, $\mathrm{i}$ form af udfrielsen fra lidelsen, som fremstilles som et uopnåeligt mål, ubestemmes hendes rejses bestemmelsesmål og hendes identitet. Hun går sine egne veje, vildveje og omveje, mens hun foretager en særegen og narrativt set normbrydende rejse i tilværelsens og identitetens vrangside. Vingefang når ikke frem til forløsningen eller til questens sejrsrige indsigtsfulde afslutning. Fortællingen afsluttes tværtimod af endnu en markering af tilværelsens ubestemmelighed, idet forfatteren simultant pointerer sine forventninger om dødens snarlige komme og, at hun i skrivende stund lever (p. 140).

\section{Konklusion}

Kræftfortællingen har sine master-narrativer, og rejsemetaforen og den konventionelle lineære rejsefortælling udgør en af de masters, der hyppigt trækkes på. 
Liselotte Vendelboe Andersens selvbiografi er nok en rejsefortælling, men den udfolder sig ganske anderledes end den kronologiske rejsefortælling. Vingefang foretager både et modtræk til rejsefortællingens, questens og restitutionens socialt accepterede genrer, såvel som til selvhjælpsfortællingens genre, hvorved den ikke bare bidrager til, men flytter grænserne for kræftfortællingens genre i det hele taget.

Kræftfortællingen har sine master-narrativer, og rejsemetaforen og den konventionelle lineære rejsefortælling udgør en af de masters, der hyppigt trækkes på. Liselotte Vendelboe Andersens selvbiografi er nok en rejsefortælling, men den udfolder sig ganske anderledes end den kronologiske rejsefortælling. Vingefang foretager både et modtræk til rejsefortællingens, questens og restitutionens socialt accepterede genrer, såvel som til selvhjælpsfortællingens genre, hvorved den ikke bare bidrager til, men flytter grænserne for kræftfortællingens genre i det hele taget.

Vingefang fremstår som en modfortælling, der baner sin egen vej igennem kræftens og kræftfortællingens landskab, som ikke er den mest direkte vej. Forfatteren er en usædvanlig opdagelsesrejsende, som er undervejs i et fint forgrenet eksistentiel og identitetsmæssig labyrint af omveje og vildveje. Hun udlever følelsen af at være dislokeret, i skabelsen af en dialog mellem flere stemmer og multiple perspektiver på livet med kræft, som genopfinder et sprog, der kan repræsentere hendes egne anskuelser og erfaringer. Perspektiverne og stemmerne udfoldes som kronotoper, dvs. tidsrum, som spejler sig i den kronotopiske konstruktion af selvet. Alene ved dialogen imellem perspektiverne på kræften og på verden, og den rastløse og hjemløse gang på stedet og i cirkler, skaber fortællingen en identitet og et rum for outsiderens kronotopisk hjemløse ytring. Denne identitet og ytring handler om permanent at måtte undvære et tilhørssted i livet og italesætter en eksistentiel hjemløshed, men fremviser sideløbende, hvordan forfatteren, imod alle odds, skaber en alternativ måde at være til på. Fortællingen optræder i sig selv, som den anden vej forfatteren har fundet frem til at gå, en vej, der både indkredser og skubber dødens ube-stemmelige og angstprovokerende endemål foran sig.

De metaforer, genrer og diskurser, som indgår i den kulturelle italesættelse af kræftsygdomme, er langt fra neutrale eller 'uskyldige'. De er tværtimod indlejret i komplekse kulturelle betydningsmønstre, som er medvirkende til at præge den måde, hvorpå sygdommen generelt anskues, italesættes og håndteres. Hele den sproglige iscenesættelse af kræft producerer en kollektiv betydning, der virker som en kulturel mekanisme, der også er i besiddelse af en vis form for automatisme, som altid vil være i fare for at skubbe det, der er anderledes væk. De kulturelt 
dominerende metaforer, genrer og diskurser sætter det uønskede og fremmede, men dog alligevel velkendte under pres.

Således kan det forekomme at være særdeles vanskeligt at skelne mellem de kulturelt overleverede, dominerende og idealiserede opfattelser af, hvordan et sygdomsforløb med kræft bør fortælles og forløbe, og hvordan mennesker faktuelt erfarer og gennemlever sygdomsforløb med kræft. En af de måder, hvorpå det er muligt at dykke ned i de problemstillinger, der optræder som en del af livet med kræft, og som præger de narrative og diskursive konventioner, som omkranser kræftsygdomme, er at undersøge, hvordan de udfoldes i selvbiografiske kræftfortællinger. Forskeren må studere det enkelte selvbiografiske vidnesbyrd i den kontekst, det udfolder sig i og forholde sig til, at der aldrig udelukkende er tale om ubesmittet personlig erfaringsnær dokumentar, men også om udsagn der taler ind i en kulturel kontekst og i et æstetisk kollektiv af metaforer, udsagn, genrer og diskurser, som det enkelte udsagn altid går i dialog med og på forskellig vis reproducerer, understøtter, nuancerer, debatterer og/eller opponerer mod.

I dette tilfælde inkorporerer selvbiografien ikke alene kroppen som et karnevalistisk topos, men optræder i sig selv som et karneval, som en kulturel ventil, der fremviser det kulturelt uønskede i skikkelse af eksistentiel fortvivlelse, sorg og desperation. Den karnevalistiske krop og det yderliggjorte individ, som bryder privatheden, symboliserer det opgør, som den publicerede kræftfortælling i dette tilfælde foretager sig på et kulturelt niveau. Liselotte Vendelboe Andersens offentligt tilgængelige udsagn bryder den tavshed, som sygdommens forsat tabubelagte skyggesider ofte er behæftet med. Hendes fortælling agerer i den henseende som en del af genrens kulturelle laboratorium, der eksperimenterer med kræftfortællingens genre og udvider grænserne for, hvad den kan rumme, mens hun vedholdende insisterer på, at kræftsygdommen i hendes tilfælde vedvarende ubestemmer, dislokerer og destabiliserer tid, sted, fortælling og identitet.

\section{Noter}

1 Flere danske selvbiografiske kræftfortællinger inkorporerer kræftrejsen som metafor og genre, eksempelvis: (Hansen, 2000; Holm, 2009; Hvid, 2005) og en enkelt af dem anvender eksplicit ridderfærden som genre og tema: (Nielsen, 1999).

2 Ridderfærden, romancen og senere dannelsesromanen inkorporerer rejsen som genrekonstituerende skema og som et tema. Således inddrager de litterære genrer rejsen som et plot, der skematiserer bevægelsen 'udrejse fra hjemmet (nedstigning) - ophold i 
en 'underverden' - hjemrejse-hjemkomst', idet sidstnævnte enten tematiseres som vellykket eller mislykket/umulig (i hhv. den prækapitalistiske og den realistiske roman).

3 Som Couser har anført som værende genrekonstituerende for amerikanske selvbiografiske brystkræftfortællinger og forklarer på følgende vis: "For obvious reasons the resolution provided by these narratives appeals to writers, editors, and readers; few people want to read (and no one wants to write) an autopathography with a tragic plot. One powerful motive in going to the considerable effort of composing a book-lenght narrative of one's illness, must be precisely to achieve closure, emotional as well as narrative" (Couser, 1997).

4 Her er der tale om en helteposition som Bakhtin beskriver som tilhørende en monologisk affattet roman, hvor 'helten er afrundet og hans betydning fast afgrænset' (Bakhtin, 1984a). Med inspiration fra Bakhtins romanteori, udpeger Frank eksistensen af to genrer henholdsvis en dialogisk og en monologisk genre i en selvbiografisk-biografisk sygdomsfortælling (Frank, 2000). Frank forklarer hvordan den monologiske sygdomsfortælling bygger på en opfattelse af sygdom og identitet, som knytter sig til begrebet om 'disruption' og dermed til en opfattelse af sygdom som en midlertidig afbrydelse af identiten. Den dialogiske fortælling begrebsliggøres i modsætning hertil med betegnelsen 'destabilization' af fortælling og identitet, som i modsætning til den monologiske 'disruption' er en permanent dvs. vedvarende narrativt, identitetsmæssigt og eksistentielt vilkår. I den monologiske fortælling er sygdomserfaringen færdigformet og fortælles på afstand. I den dialogiske fortælling fortælles sygdomsprocessen undervejs, mens sygdomsforløbet gennemleves, mens erfaringen gøres, helt tæt på.

5 Liselotte Vendelboe Andersen døde sommeren 2009.

6 (Freud, 1919)

7 Den svenske filosof Fredrik Svenaeus har udarbejdet en 'sygdommens fænomenologi', der bl.a. begrebsliggør hjemløsheden og sygdomskroppens un-heimliche træk (Svenaeus, 2000a; Svenaeus, 2000b).

8 Begrebet blev introduceret i Foucaults essay Of other spaces fra 1967.

\section{Tak}

Jeg takker professor Helle Johannessen for indsigtsfulde kommentarer til artiklen.

\section{Referencer}

Avrahami,E. (2007). The Invading Body: Reading Illness Autobiographies. University of Virginia Press.

Bachelard,G. (1958). The poetics of space. The classic look at how we experience intimate places. Boston: Beacon Press.

Bakhtin,M.M. (1982). The Dialogic Imagination: Four Essays. University of Texas Press.

Bakhtin,M.M. (1984a). Problems of Dostoevsky's Poetics. University of Minnesota Press. 
Bakhtin,M.M. (1984b). Rabelais and His World. Bloomington, IN: Indiana University Press. Bamberg,M., \& Andrews,M. (2004). Considering Counter-Narratives: Narrating, Resisting, Making Sense (Studies in Narrative).

Bech-Jørgensen,B. (2002). Usædvanlige tidsstrategier. Social Kritik, 82 69-76.

Breast Cancer Fund (1998). Art.Rage.Us.: The Art and Outrage of Breast Cancer. San Francisco, CA: Chronicle Books.

Bro,S. (2004). Sara Bros dagbog. Copenhagen: People's Press.

Brockmeier,J., \& Carbaugh,D.e. (2001). Narrative and Identity: Studies in Autobiography, Self and Culture. John Benjamins Pub. Co.

Brody,H. (2003). Stories of Sickness. Oxford University Press.

Brooks,P. (1993). Body Work: Objects of Desire in Modern Narrative. Harvard University Press.

Broom,D. (2001). Reading breast cancer: reflections on a dangerous intersection. Health, 5(2), 249-268.

Broyard,A. (1992). Intoxicated by My Illness. And Other Writings on Life and Death. New York: Fawcett Columbine.

Bruhn,J. (2005a). 'Useful if Treated with Caution'. Carnivalization in Don Quijote. In E. Østrem, M.B. Bruun, N.H. Petersen, \& J. Fleischer (Eds.), The Cultural Heritage of Medieval Rituals. Genre and Ritual- (pp.187-207).

Bruhn,J. (2005b). Romanens tænker. M. M. Bachtins romanteorier. København.

Casarett,D., Pickard,A., Fishman,J.M., Alexander,S.C., Arnold,R.M., Pollak,K.I., \& Tulsky,J.A. (2010). Can metaphors and analogies improve communication with seriously ill patients? J.Palliat.Med, 13(3), 255-260.

Conway,K. (2007). Illness and the Limits of Expression. Ann Arbor, MI: University of Michigan Press.

Couser,G.T. (1997). Recovering Bodies: Illness, Disability, and Life Writing. Wisconsin: University of Wisconsin Press.

Couser,G.T. (2009). Signifying Bodies: Disability in Contemporary Life Writing. University of Michigan Press.

Crane-Okada,R. (2007). A compass for the cancer journey: scientific, spiritual, and practical directives. Oncol.Nurs.Forum, 34(5), 945-955.

De certeau,M. (1978). The practice of everyday life. University of California Press.

DeShazer,M.K. (2005). Fractured Borders: Reading Women's Cancer Literature. University of Michigan Press.

Ehrenreich,B. (2009). Bright-Sided. How the Relentless Promotion of Positive Thinking Has Undermined America. New York: Metropolitan Books.

Farquhar,M.C., Barclay,S.I., Earl,H., Grande,G.E., Emery,J., \& Crawford,R.A. (2005). Barriers to effective communication across the primary/secondary interface: examples from the ovarian cancer patient journey (a qualitative study). Eur.J.Cancer Care (Engl.), 14(4), 359-366.

Fawcett,J.T.N. (2011). Cancer: a journey of discovery. In J.T.N. Fawcett, \& A. McQueen (Eds.), Perspectives on Cancer Care: Blackwell.

Flyvbjerg,B. (2006). Five misunderstandings about case-study research. Qualitative Inquiry, 12(2), 219-245.

Flyvholm,F. (2008). På kanten af livet. En beretning om kræft og optimisme. København: Gyldendal. 
Frank,A.W. (1991). At the Will of the Body. Reflections on Illness. New York: First Mariner Books Edition 2002.

Frank,A.W. (1995). The Wounded Storyteller: Body, Illness, and Ethics. Chicago: The University of Chicago Press.

Frank,A.W. (2000). Illness and Autobiographical Work: Dialogue as Narrative Destabilization. Qualitative Sociology, 23(1).

Freud,S. (1919). Das Unheimliche. Imago.Zeitschrift für Anwendung der Psychoanalyse auf die Geisteswissenschaften 297-324.

Garrison,K. (2007). The personal is rhetorical: War, protest, and peace in breast cancer narratives. Disability Studies Quarterly, 27(4), 1-13.

Gemzøe,A. (2003). Tid og rum i Bachtins værker. In N.M. Andersen, \& J. Lundquist (Eds.), Smuthuller. Perspektiver i dansk Bachtin-forskning (pp.63-88).

Gibbs,R.W., Jr., \& Franks,H. (2002). Embodied metaphor in women's narratives about their experiences with cancer. Health Commun., 14(2), 139-165.

Gyldenkilde,L. (1999). Tanker ved et køkkenbord. Møntergården.

Hansen,I. (2000). Midt i livet - på vej mod døden og livet. Valby: Unitas forlag.

Harrington,K.J. (2012). The use of metaphor in discourse about cancer: a review of the literature. Clin.J.Oncol.Nurs., 16(4), 408-412.

Hawkins,A.H. (1993). Reconstructing Illness: Studies in Pathography. West Lafayette, Ind.: Purdue Univ. Press.

Henriksen,N. (2011). Om at leve med og håndtere en kræftsygdom: et litteraturstudie af danske bogpublicerede kræftfortællinger - med særligt fokus på eksistentielle og æstetiske aspekter (Ph.d.-afhandling).: Det Sundhedsvidenskabelige Fakultet, Syddansk Universitet.

Henriksen,N., \& Hansen,H.P. (2009). Marked bodies and selves: a literary-semiotic perspective on breast cancer and identity. Commun.Med., 6(2), 143-152.

Henriksen,N., Tjornhoj-Thomsen,T., \& Hansen,H.P. (2011). Illness, everyday life and narrative montage: the visual aesthetics of cancer in Sara Bro's Diary. Health (London), 15(3), 277-297.

Hjelm,E., Hartwig,K., \& Berterö,C. (2007). An Inevitable Journey by Train: Nurses' Narratives About Palliative Care. Journal of Hospice and Palliative Nursing, 9(4), 206-211.

Holm,B. (2009). Den sidste kilometer - en bog om at blive klogere. People'sPress.

Hvid,T. (2005). Livet mod døden. Aarhus: Forlaget Modtryk.

Kendall,M., \& Murray,S.A. (2005). Tales of the Unexpected: Patients' Poetic Accounts of the Journey to a Diagnosis of Lung Cancer: A Prospective Serial Qualitative Interview Study. Qualitative Inquiry, 11(5), 733-751.

Koch,L. (2008). De forsinkede. Ugeskr Læger, 170(45), 3687.

Kristeva,J. (1986). Word, Dialogue and Novel. In M. Toril (Ed.), The Kristeva Reader (pp.3462). Oxford: Basil Blackwell.

Lakoff,G., \& Turner,M. (1989). More than Cool Reason. A Field Guide to Poetic Metaphor. Chicago \& London: The University of Chicago Press.

Leydon,G.M., Bynoe-Sutherland,J., \& Coleman,M.P. (2003). The journey towards a cancer diagnosis: the experiences of people with cancer, their family and carers. Eur.J.Cancer Care (Engl.), 12(4), 317-326. 
Lock,C. (2001). Double Voicing, Sharing Words: Bakhtin's Dialogism and the History of the Theory of Free Indirect Discource. In J. Bruhn, \& J. Lundquist (Eds.), The Novelness of Bakhtin. Pespectives and Possibilities: Museum Tusculanum Press.

Lorde,A. (1980). The Cancer Journals. San Francisco, CA: Aunt Lute Books.

Miller,J.H. (1995). Topographies. Stanford University Press.

Nanton,V., Docherty,A., Meystre,C., \& Dale,J. (2009). Finding a pathway: information and uncertainty along the prostate cancer patient journey. Br J.Health Psychol., 14(Pt 3), 437458.

Nielsen,H.O. (1999). Tredje halvleg. Om en mands møde med kræften og sig selv. Nielsens. Peeren,E. (2008). Intersubjectivities and Popular Culture. Bakhtin and Beyond. Stanford University Press.

Penson,R.T., Schapira,L., Daniels,K.J., Chabner,B.A., \& Lynch,T.J., Jr. (2004). Cancer as metaphor. Oncologist., 9(6), 708-716.

Radley,A. (2009). Works of Illness. Narrative, Picturing and the social Responce to Serious Disease. Inker Men Press.

Reisfield,G.M., \& Wilson,G.R. (2004). Use of metaphor in the discourse on cancer. J.Clin. Oncol., 22(19), 4024-4027.

Ricoeur,P. (1985). Time and Narrative, Vol. 1-3. Chicago: University of Chicago Press.

Sandaunet,A.G. (2008). A space for suffering? Communicating breast cancer in an online self-help context. Qual.Health Res., 18(12), 1631-1641.

Seale,C. (2002). Cancer heroics: A study of news reports with particular reference to gender. Sociology-the Journal of the British Sociological Association, 36(1), 107-126.

Segal,J.Z. (2007). What is a story of breast cancer?

Semino,E., Heywood,J., \& Short,M. (2004). Methodological problems in the analysis of metaphors in a corpus of conversations about cancer. Journal of Pragmatics, 36 1271-1294.

Skott,C. (2002). Expressive metaphors in cancer narratives. Cancer Nurs., 25(3), 230-235.

Sontag,S. (1989). Illness as Metaphor and AIDS and Its Metaphors. Picador.

Spence,J. (1998). Putting Myself in the Picture: A Political, Personal and Photographic Autobiography. Seattle, WA: Real Comet Press.

Stacey,J. (1997). Teratologies. A Cultural Study of Cancer. London \& New York: Routledge. Ströker,E. (1977). Philosophische Untersuchungen zum Raum. Frankfurt am Main: V. Klostermann.

Svenaeus,F. (2000a). Das unheimliche - towards a phenomenology of illness. Med.Health Care Philos., 3(1), 3-16.

Svenaeus,F. (2000b). The body uncanny - further steps towards a phenomenology of illness. Med Health Care Philos., 3(2), 125-137.

Teucher,U. (2003). The Therapeutic Psychopoetics of Cancer Metaphors: Challenges in Interdisciplinarity. History of Intellectual Culture, 3(1).

Tygstrup,F. (1999). Det litterære rum. Passage.Tidskrift for litteratur og kritik, 31/32.

Tygstrup,F. (2000). Kronotopisk identitet. A propos Morten Søndergaards Ubestemmelsessteder. Kritik, 144.

Tygstrup,F. (2001). Byens Kronotop. In M. Barlyng, \& F. Tygstrup (Eds.), (p.-Den litterære opfindelse af byen). København: Forlaget Spring.

Yates,P. (2004). Cancer Care Coordinators: Realising the Potential for Improving the Patient Journey. Cancer Forum, 28(3), 128-132. 
